\title{
Media Construction and Radicalism
}

\author{
Darajat Wibawa \\ Faculty of Da'wah and Communication \\ UIN Sunan Gunung Djati \\ Bandung, Indonesia \\ darajatwibawa@yahoo.com
}

\begin{abstract}
The media has a role in changing of the views, attitudes, and behavior of people, groups, organizations, cultures and social systems. The media able to construct events in the field. Therefore, the media can be used for various purposes, including radicalism and terrorism publishing by certain parties. Radicalism and terrorism message can be the credo in society, so it is can be the threat to comfort and national resilience. If the state ideology is not sturdy, it will have an impact on decreased of national resilience. The question is, how the media role in spreading and dispel of radicalism? To answer the question, researchers dissected by using qualitative approach, phenomenology tradition. The result shows, radicalism and terrorism through media able to change of human knowledge, feeling and behavior.
\end{abstract}

Keywords - radikalism; media; influence; communication; cognitive

\section{INTRODUCTION}

Countries in the world including Indonesia country, is currently faced with the problems and threats of radicalism. Radicalism in addition to being a threat to comfort, tranquility, and concern is also a threat to ideological resilience. Radicalism has emerged for a long time, but the bombing incident that once occurred in Indonesia and in other countries, as if able to deliver the event as the contemporary enemies as well as the most enduring for humans. Although some actors of radicalism have been found and then punished, the fear of radicalism continues to haunt.

Radicalism has various definitions depending on the point of view of each. According to Kamus Besar Bahasa Indonesia, radical has three meanings: 1) Fundamentally. 2) Extremely hard to demand change. 3) Going to forward thinking or acting. Based on that definition, radicalism can be interpreted as an attitude or understanding of the extreme, revolutionary and militant to fight for change from the mainstream of the community [1]. Radicalism does not have to appear in a form that smells of physical violence. Ideology of thought, demonstration of opposing attitudes and want to change the mainstream can be classified as a radical attitude.

Radicalism emergence is very complex and complex, ranging from world politics to multifactorial factors such as social, political, economic, and cultural. In addition, the existence of radicalism combined with low education, poverty, culture, and social life is believed to trigger radicalism that leads to violence, extremism and ultimately forming terrorist groups. However, it seems that ideology and theology are the two most fundamental components in the movement of terrorism.

Radicalism acts cannot be interpreted an act of murder only, but as an action of communication process by certain groups in a systematic and planned way, so that ultimately get the sympathy of the community. Radicalism run by extremists and then published by media, in fact no other aim to voice his political attitude.

Attempts to get the attention of the media seem to be demonstrated by some acts of terrorism that had gained international attention, such as the September 11, 2001 action directed at the World Trade Center Building, which at that time also media publicize it. In Indonesia, suicide bombings in Bali, the Australian embassy, as well as many other places also get publicity from media. Even with the development of communication and information technology, terrorist groups that embrace the message of radicalism utilize social networking on the internet to spread publicity, by providing blogs on the internet filled by messages according to radicalism groups.

In reform era, Indonesia became one of the countries whose mass media industry is growing rapidly [2]. In this era, information submitted by the media spread faster and can be accessed at any time. The information packaged in a news as well as a feature of violence, radicalism and radicalism is believed to give more value, so it is not surprising that the media are competing to present the report with complete, interesting, comprehensible and even store it in the main news category. The massive role of the media is well understood by radical groups, therefore the existence of media is greatly exploited by radicalism.

\section{RESEARCH METHODS}

The method used in this research is descriptive, while the data retrieval technique is done by literature study. Descriptive method can be interpreted as a problem-solving procedure that is investigated by describing the state of the subject or object in the research can be people, institutions, communities and others who are now based on the appear facts.

According to Nazir descriptive method is a method in examining the status of a group of people, an object, a set of conditions, a system of thought or a class of events in the present [3]. The purpose of this descriptive study is to create a 
description, description, or painting systematically, factually and accurately about the facts, properties and relationships between phenomena investigated. Meanwhile according to Sugiyono, descriptive method is a method used to describe or analyze a research results but not used to make wider conclusions [4].

The study of literature is the way used to collect data or sources related to the topics raised in a study. According to Burhan Bungin the literature method is one of the data collection methods used in social research methodology to trace historical data [5], while Sugiyono literature is a record of past events in the form of writings, drawings, or monumental works of someone [4].

\section{RESULTS AND DISCUSSION}

The results of this study indicate, construction of media to radicalism can be grouped into three categories namely cognitive, feeling and behavioral aspects.

\section{A. Cognitive}

Cognitive is the ability to think reason and solve. Cognitive ability will facilitate in mastering the general knowledge of the wider, so as to be able to perform its functions fairly in interaction with society and everyday environment.

According to Kamus Besar Indonesia, cognitive has two meanings namely, 1) Related to or involving cognition. 2) Based on empirical factual knowledge [1]. While the cognition according to Kamus Besar Indonesia has three meanings, namely: 1) Engagement or the process of acquiring knowledge (including awareness and feelings, etc.) for the effort to recognize something through their own experience. 2) Process, recognition and interpretation of the environment by a person. 3) Knowledge acquisition results [1]. Cognition refers to all mental activities associated with thinking, knowing, and remembering [6]. While according to Drever, cognition is a general term that includes all models of understanding, namely perception, imagination, catching meaning, judgment and reasoning [7].

The media has a contribution in building and changing the cognitive aspects of the reader, audience, and audience. Through mass media, audiences obtain information about objects, goods or places we have never visited directly [8] thus hinting, information presented by radical groups will fill the cognition of every individual in society without any compulsion to understand it. In other words, if the public is aware of radicalism's information, the purpose of filling, shaping and changing the cognition of its audiences by radical groups, can be said to be successful. Mass media is the extension of our sense apparatus [9]. Through to media, people are getting information about a variety of information.

The media reports the real world selectively, thus the media tends to influence the formation of images of a biased and lame social environment. Therefore, the so-called stereotype, which is the general picture of an individual, a group, a profession or an unchanging society, is cliche and often lopsided and incorrect. The image of a person, also formed by the agendasetting role. Setting the agenda assume, media filter the news, articles, or writings to be broadcast [9]. Typically, the media organize messages packaged in a news item as well as features that will be presented to the public. The priority is of course tailored to what is the priority of the community so that what is considered important by society then it is considered important also by the media. If people consider important information about radicalism, it will be considered important by the media.

The media not only able to form the image and agenda setting that is part of the cognitive aspect alone, but able to form prosocial effects. That is, media can provide more benefits of knowledge than previously obtained. The media such as newspapers, television and radio have an enormous role in shaping the prosocial effects of their audience, so that if this role is truly exploited by radical groups then the idea of radicalism will spread by itself.

\section{B. Feeling}

Feeling is more identified with the affective aspects of a person in the view of communication psychology. According to Kamus Besar Bahasa Indonesia, affection or feeling has three meanings, namely: 1) With regard to feelings (like fear, love). 2) Affects circumstances, feelings and emotions. 3) Have a style or meaning that shows feelings (about the style of language or meaning). Human being in response is directed by reasoning and judgment, but at times, certain emotional impulses interfere and influence his thinking and behavior. Behaviors that are accompanied by certain feelings can be regarded as affective colors that are sometimes strong, weak or unclear. The effect of affective color will result in a deeper feeling.

The media has a role in shaping and changing the feelings of the reader, audience and audience. Aspects of feeling may be have higher levels when compared with cognitive aspects. The feeling of the message delivered through the media is not only focused on the aspect of the reader, listeners and audience, but further from that in the feeling of the message delivered to the reader, the listener and the viewer seep into the inner so that the message is not only to meet the need for information only but to feel what actually happens through the work that has been packaged into journalistic work made by journalists.

In other words, in the sense feeling the purpose of mass communication is not just to inform the audience but more than that, after knowing the information it receives, the audience is expected to feel it. [8]. There are at least two aspects that can arise related to the effects of media affection, namely the formation and change of attitude, and emotional stimulation. Attitude is determined by image. In turn, the image is determined by the source of information. Among the most important sources of information is the media. Newspapers, television, and radio have a great impact on the affection of their audiences.

People seek entertainment often because they want to let go of their emotional stress from the weight of everyday life. They want to appease the feelings by reading comics, watching movies, and enjoying entertainment on radio and television. In addition, entertainment also serves as an important element of a good life, can even function as a status symbol. At least 
entertainment helps one feel happy. Respondents who are comic readers more have a higher sense of humor.

Comic's entertainment, novels, or movies or cartoons published by the media are able to influence the feeling of the reader or audience better than the news in newspapers or television. Community groups that use the media as entertainment, have a high imagination. Their life priorities are also more varied, and tend to prioritize the fulfillment of affection needs. Mass media is able to bring audiences in a new atmosphere so that it can get out of the previous situation is tired and boring. That is, the feeling aspect owned audiences become the main shooting of the media so as to shape as well as change attitudes, and cause emotional stimulation. Therefore, the existence of the media cannot be displayed, including by radicalism group.

\section{Feeling}

Behavioral effects are the result that arise in the audience in the form of behavior, actions and activities. The scene of tenderness, wisdom and kindness leads to the reader, his audience and audience to be a gentle, wise and kind person. Conversely, scenes from the media spiced with violence may be causing people to become violent. All messages that are packaged and then published through the media have different behavioral effects. There are at least two effects that can be categorized into this behavioral, namely behavioral prosocial effects and aggression.

One of the prosocial behaviors is to have skills that benefit both themselves and others. Such skills are usually obtained from interpersonal channels such as parents, superiors, coaches, or teachers. In today's modern world, some of the tasks of educating have been the media. The media not only have a behavioral prosocial effect, it also has an aggressive effect. According to Buss, aggression is a behavior undertaken to harm, threaten or endanger individuals, objects that are subjected to such behavior either physically or verbally and directly or indirectly. Aggressions are behaviors intended to injure others or damage property.

The media has a role in setting the tendency of a person to act violently. Much researchers has shown that media have contributed to shaping violence in society. Even in the United
States since the 1950 researchers were interested in the relationship between violent scenes watched with aggression. This study was partly born of anxiety due to increasing violence in television. Even in Indonesia, we often hear children do violence, or commit suicide after seeing television.

The media has contributed in shaping prosocial behavioral as well as aggression to the readers, viewers and listeners. The aggression aspect of radicalism can be used as a basic ingredient to attack anyone desired by exposing the facts about the violence they are perpetrated, so that the readers, viewers and listeners feel more confident.

\section{CONCLUSIONS}

The media has a powerful role in constructing the message of radicalism that communicated to the public. Media has the ability to forming and change various aspects including:

- Be able to forming and change the cognition aspect of readers, viewers and listeners.

- Be able to forming and change the feeling aspect of the reader, viewers and listeners.

- Be able to forming and change the behavioral aspects of the reader, viewers and listeners

\section{REFERENCES}

[1] Kamus Besar Bahasa Indonesia, 2007.

[2] Wibawa, Darajat, "Meraih Profesionalisme Wartawan”, Mimbar, Jurnal Sosial dan Pembangunan, Volume XXVIII, No.1, 2012, pp113-122

[3] Nazir, Mohammad, "Metode Penelitian", Ghalia Indonesia, Jakarta 1988.

[4] Sugiono, "Memahami Penelitian Kualitatif”, Bandung, Alfabeta 2005.

[5] Burhan, Bungin, "Penelitian Kualitatif; Komunikasi, Ekonomi, Kebijakan Publik dan Ilmu Sosial Lainnya", Jakarta, Kendcana, 2008.

[6] Myers, "Cognition, or mental activity", Unv,England, 1996.

[7] Draver, "Dictionary of Psychology", Ijn, USA, 2002.

[8] Siti Karlinah, "Komunikasi Massa", UT, Jakarta, 1999.

[9] Jalaluddin Rakhmat, "Psikologi Komunikasi", Remaja Rosdakarya, Bandung, 2007 